\title{
13 China's carbon-energy policy and Asia's energy transition from carbon leakage, relocation, and halo perspectives
}

\author{
Conclusions and the future
}

\author{
Akihisa Mori
}

\section{Research questions of this book revisited}

The Paris Agreement spurs system transformation toward carbon neutral and climate resilient development around the world. Green recovery from the COVID-19 pandemic coupled with digital transformation intensifies global competition over green technologies, infrastructure, systems, and platforms, prompting governments to renovate policies and institutions, and to redirect expenditure for developing infrastructure.

China emerges as a top runner in the global competition amid the COVID-19 pandemic. Strict city-wide lockdown, large-scale surveillance supported by digital monitoring systems, and preparation of made-inChina medical facilities, supplies, and vaccines to reduce the epidemic enable the country to accelerate digital transformation and to revitalize production of conventional goods and services. The 14th Five Year Plan (FYP, 2021-2025), the first FYP after the commitment to carbon neutrality by 2060 at the United Nations General Assembly, raises the ratio of non-fossil fuel sources in China's energy mix from 15\% in the 13th FYP to around $20 \%$. The plan also sets targets to build $1200 \mathrm{GW}$ of wind and solar capacity by 2025 - higher than that of coal power capacity in 2016 (Braun, 2021).

The ambitious targets and industrial fostering policies for wind and solar power have boosted Chinese manufacturers. They have capitalized on domestic and foreign markets to enjoy economies of scale, lowering leveraged cost and upgrading technologies. As a result, wind and solar power become competitive with coal power (IRENA, 2020). An increasing number of companies around the world import wind and solar power technologies from China to increase installed capacity, which is expected to generate carbon halos effect in the end.

However, a large-scale integration of renewable-energy-sourced electricity (RES-E) into the grid goes beyond a change in energy mix to demand a whole system change from fossil fuel-intensive, vertically integrated, and 
hierarchical and centrally controlled electricity supply system toward a capital-intensive, distributed, and smart grid-based electricity system. As pointed out in Chapter 2, the system change poses three challenges: taming the incumbent influential regime actors; reconciling the compelling narratives of "energy for development," "energy for industrial development," and "energy for all"; and reducing uncertainty and unpredictability of the new system and the transition process.

In addition, an industrial transformation from a polluted "factory of the world" to a clean, green producer of homegrown high-tech and digitalized goods and services reduces domestic pollution-production, accelerates consolidation, and generates massive unemployment in pollution-intensive sectors such as coal and coal-intensive industries. A perception of an unpromising future can incentivize these industries to geographically diversify their investments in countries with loose regulations, increasing the probability of causing carbon relocation.

Against these conflicting perspectives, this book raises three research questions.

a How has China's carbon-energy policy incentivized outward FDI in coal power and renewable-energy-sourced electricity (RES-E) projects and exports of these technologies?

b How have Chinese outward FDI in and exports of coal power and RES-E generated energy transitions in host countries and caused carbon leakage, relocation, and halos?

c Can regional connectivity be a countermeasure to minimize carbon relocation and enhance the carbon halo effect in the context of ChinaAsia energy relations?

\section{China's carbon-energy policy and firms' responses}

A scenario input-output analysis in Chapter 3 finds that a large-scale integration of RES-E reduces $\mathrm{CO}_{2}$ emissions without significantly affecting GDP and employment at the national level. However, coal power and its related industries such as mining, coal products, and transportation will have negative impacts on output and employment. Although larger job creation effects of the solar power industry can mitigate the negative impacts of an energy switch as opposed to wind power, it does not mean that employees working at coal power or mining will get jobs at solar power manufacturing. Improper regulation of transaction cost associated with the energy transition can be a driving force for incumbent coal power generation companies to geographically diversify their business portfolio into foreign countries, joining in foreign coal power projects. The Chinese government may push their outward FDI to mitigate the transaction costs of the transition, at the cost of an increase in $\mathrm{CO}_{2}$ emissions in foreign countries. 
A retrospective analysis of Chinese solar photovoltaic (PV) manufacturers in Chapter 4 shows that successful commercialization of the passivated emitter and rear cell (PERC), as well as investments in PV module manufacturing equipment, has enhanced technological capabilities and the competitive edge of emerging Chinese manufacturers, eliminating incumbent manufacturers from the domestic market. The enhanced competitive edge, coupled with the phase-out of feed-in tariff (FiT) for solar power in China, drives Chinese manufacturers toward exports, supplying trade partners more efficient solar PV at a lower price.

Despite the stronger competitive edge, Chinese power companies, manufacturers, and developers have made much less investments in foreign RES-E projects than coal power, as shown in Chapter 5. Although this result can be biased against RES-E projects, most of which are small-scale and out of coverage of the database on which the analysis is based, the chapter finds that Chinese power project developers have proactively responded to the stringent regulations and the Belt and Road Initiative (BRI) to increase investments and contracts in foreign power projects.

Given the continuous increase in installed coal power generation capacity in China, this result implies that China's carbon-energy policy and BRI have incentivized Chinese power generators, manufacturers, and developers to make outward FDI in power projects, but have not relocated their plants to foreign countries.

\section{Impacts on energy transitions, carbon relocation, and halos in Asia in action}

A computable general equilibrium (CGE) model analysis in Chapter 6 shows that China's outward FDI in coal power projects is likely to increase global $\mathrm{CO}_{2}$ emissions, but the extent varies by energy mix in power generation and non-electricity sectors. China's outward FDI in power projects in coal-rich countries, especially those rich in low-quality coal such as India and to a lesser extent Indonesia, will increase $\mathrm{CO}_{2}$ and sulfur dioxide $\left(\mathrm{SO}_{2}\right)$ emissions in host countries that significantly outweighs a decrease in emissions in China. Furthermore, a declining demand for coal in China's electricity sector may reduce the global coal price, which may stimulate coal consumption in non-electricity sectors in both China and coal-dependent countries. In contrast, FDI in coal-poor countries or those using high-quality coal may not increase emissions so much as to outweigh a decrease in China.

Matching econometrics in Chapter 7 elucidates that renewable energy policies, such as renewable portfolio standard and a FiT, significantly increase imports of wind and solar power components from Asia-dominated by China to satisfy the renewable energy target in host countries. However, host countries experienced difficulties in increasing imports when Chinese manufacturers directed production capacity to fill out domestic demand 
stimulated by the same policies in Asian countries, typically in China. Coupled with the recent investments in production capacity for PERC PV by Chinese manufacturers, renewable energy policies are more likely to increase imports of PERC PV.

The impacts on energy transitions and carbon relocation and halos effects are more or less similar in India, Indonesia, and Vietnam. As shown in Chapter 5, they were largest host countries of China's outward FDI in coal power projects when the Chinese government began stringent carbon-energy-environmental policies and the BRI. To invite Chinese investors, financiers, and developers, they have changed the elements of complementarities along the value chain of the electricity supply system. They reallocated domestic coal to new coal power plants that were built by Chinese investments, financial supports, or under the engineering, procurement, and construction contracts with Chinese companies. The Indonesian government was forced to provide full guarantee to the credit risk of the state-owned utility to ensure loan repayment to Chinese financial institutions (Mori, 2020). The consensus of interest between China and host countries resulted in the large Chinese investments in and developments of coal power plants, enhancing generation capacity and enabling electricity supply to wider areas at an affordable cost, but at the cost of increase in air pollution and $\mathrm{CO}_{2}$ emissions. In other words, China's carbon-energy policy and BRI caused carbon relocation effect by stimulating outward FDI in coal power projects in an unintentional and indirect manner.

China's presence as a technology supplier remains unchanged or even larger in the transition toward an RES-E-based electricity system. Chinese manufacturers compete to supply a range of solar PV modules from lowto high-end consistent with the needs of host countries, whereas manufacturers in these host countries tend to have insufficient capability to supply components and insufficient product branding or quality, trust, or loyalty. However, the Chinese government restricts exports of solar PV cells, not to mention foreign investments in manufacturing plants, to prevent manufacturers in host countries from enhancing technological capabilities through reverse engineering (Chapter 8). A number of domestic and international developers and independent power producers (IPPs) invest in solar power projects under a FiT or join reverse auctions to win concessions of solar power projects, bringing in imported solar PV modules from China. As a result, the most of the host countries have not succeeded in developing domestic solar PV manufacturers and national technological capabilities for developing solar PV. In other words, they have not gained carbon halos effects through Chinese exports of solar PV.

Coupled with the excess installed capacity of coal power in the Java-Bali Grid and the lock-in into a coal-based electricity supply system, the lack of carbon halos effects prompts the Indonesian government to narrow the 
scope of favorable RES-E policies for electrification in off-grid areas. In India, coupled with divergences in political, economic, and strategic interests, it triggers repercussions from overdependence on Chinese manufacturers, leading to an anti-dumping duty on solar cell (Chapter 9).

Japan also goes through the negative feedback effect without having the carbon halo effects. Chinese solar PV manufacturers emerged as competitors to Japan's once-world-leading manufacturers. The Japanese government has placed energy security as the top priority in energy policy, strengthening lock-in and coalition of nuclear power in the narrative of optimal energy mix (Mori, 2019). Japanese solar PV manufacturers and solar power developers are required to contest the nuclear power-based, vertically integrated electricity supply system to scale them up and gain economies of scale to compete with Chinese ones. The coalition is so powerful that Japanese solar PV manufacturers and solar power developers fail to do so, resulting in large market deployment by Chinese solar PVs. Chapter 10 finds that Japanese manufacturers' loss of a competitive edge redirects the principle of Japanese energy policy toward technology self-sufficiency through research and development (R\&D) of advanced RES-E technologies, and diversification of energy sources to ensure energy security, rather than anti-dumping measures.

The carbon relocation and a lack of carbon halo effect in the electricity sector do not imply that China is generating carbon leakage. Chapter 11 shows that China reduced exports of $\mathrm{CO}_{2}$ emissions to Japan during 2005-2015, implying shrinking carbon leakage from Japan. This reduction accrues to the decrease in carbon intensity in electricity, chemical, and transport equipment sectors, as well as the shift of exports toward less carbon-intensive sectors. In contrast, the country increased exports to Indonesia and Vietnam in the same period, implying increasing carbon leakage from them. This comes from the rise in carbon intensity in electricity generation in both countries that rapidly shifted toward coal-based power generation, as well as increase in the trade volume. These findings suggest that China may increase $\mathrm{CO}_{2}$ emissions globally by increasing imports of carbon-intensive goods from countries with higher carbon intensity even if the country reduces the emissions domestically.

To summarize the results, China's outward FDI in coal power projects has pushed transitions to and strengthened lock-in into a coal-based electricity system, thus increasing $\mathrm{CO}_{2}$ emissions. In contrast, China's outward FDI and exports of solar PV technologies have generated carbon halo effect marginally at best, and discouraged host country governments from implementing favorable RES-E policies in the extreme. These outward FDI and exports might have caused partial carbon leakage in the electricity sector, because Chinese power companies continue to operate most of the efficient coal power plants within China. Nonetheless, they can add on global increase in $\mathrm{CO}_{2}$ emissions because they have increased coal power and carbon 
intensity in industries in host countries and China's shift to less carbonintensive industries increases imports of carbon-intensive goods from these host countries.

\section{Regional market integration as a countermeasure?}

The integrated assessment of regional electricity market integration in Chapter 12 shows that it is regionally efficient location of electricity generation rather than optimization of the energy mix through the reduction of new power plants that will generate newly installed capacity for fossil fuel power and reduce $\mathrm{CO}_{2}$ emission in the region by regional market integration. Countries with low levelized cost of electricity (LCOE) in coal power-due to easier access to cheap coal, coal power technology, or lax environmental regulations - are more likely to increase coal power generation and $\mathrm{CO}_{2}$ emissions, whereas those with low LCOE in RES-E, typically China, will reduce coal power generation and $\mathrm{CO}_{2}$ emissions.

This finding implies that regional electricity market integration and connectivity is more likely to cause carbon relocation effect than carbon halo effect unless host countries develop domestic high-tech RES-E technologies and capitalize on the integrated regional market to enjoy the economies of scale for RES-E technologies. This implication is in line with Khosla et al. (2020), who argued the essential role of public sector enterprises (PSEs) in leveraging economies of scale, reinforcing complementarities between global value chains and related domestic technology policy choices, and strengthening domestic academia-industry $\mathrm{R} \& \mathrm{D}$ linkages as an integral part of the energy policy mix.

However, findings from the analysis of Chinese solar PV manufacturers in Chapter 4 suggest that the chances may become less and less likely. Chinese manufacturers have already commercialized the PERC and enhanced competitive edge against solar PV manufacturers around the world, and against coal power. As pointed out in Chapter 5, they have invested in few solar PV manufacturing plants in foreign countries, and thus spillover effect can hardly be expected.

To summarize, regional market integration and connectivity cannot be expected as a panacea.

\section{The future}

This paper has two main contributions to the arguments over international trade, FDI, and the environment. First, it expands the concept of pollution haven and halos and carbon leakage to define carbon relocation and halos that explain impacts of both outward FDI in power projects and international trade of RES-E technologies on $\mathrm{CO}_{2}$ emissions in host countries. 
Second, it adds empirical novelty to the underlying mechanisms that generate carbon relocation and halos, the extent carbon relocation and halos in the electricity sector can contribute to carbon leakage in a country, and effectiveness of regional electricity market integration and connectivity as countermeasures to carbon relocation.

Novelty invites the next research agenda. We point out three of them as future research directions.

First is to explore the effectiveness of emerging innovative green finance instruments. The global divestment movement gives additional driving force by pressuring multilateral development banks, public export credit agencies, financial institutions, institutional investors, and businesses in OECD member countries to move out of fossil fuel industries, including coal power plants. Local protests against coal power become fierce around the world. In response, some developing countries such as Vietnam, Bangladesh, and Kenya give up advancing China-backed coal power projects under preparation.

The movement itself does not provide any alternatives that can reconcile the divestment with other objectives of energy policy such as energy security and energy justice. As illustrated in Figures 2.1 and 2.2, the transition from fossil fuel-intensive toward a capital-intensive RES-E-based electricity system is accompanied by changes in the elements of complementarities in the electricity system, which requires investments in and rearrangements of the elements of technologies, organizations, institutions, and infrastructure. Traditional formal financial institutions are generally less willing to make loans for these new capital-intensive power generation plants (Haskel and Westlake, 2018).

Green finance such as green bonds, green banks, and communitybased green funds can potentially overcome financial bottlenecks (Sachs et al., 2019). Pension funds are providing financial capital for these new innovative financial instruments (Rifkin, 2019). Environmental, social, and governance (ESG) investments have gained momentum. If green finance provides financial capital that enables host countries to reconcile divestment and other energy purposes, they will be attracted to use it to change the elements of complementarities toward RES-E-based electricity system instead of relying on Chinese outward FDI and development finance.

Second is to investigate tipping points and decisive factors that affect incumbent influential firms' responses. Firms are not homogeneous. They have different perceptions on damages caused by policy and institutional changes, and are diverse in knowledge, prior experience, assets positions, and organizational culture on sustainable practices (Teece et al., 1997; Hartmann et al., 2020). As responses to policy and institutional changes prompt them to take heterogeneous responses, resulting in changes to their competitive edge and market share, they perceive conflicts of interest among 
them and they may become reluctant to take collective actions or lobbying to the government. Such dynamics will generate policy feedback effects, coevolving policy and institutions, and firms' strategies (Mori, 2021). Given that complete or partial relocation of industrial plants, industry, and production processes can be categorized as a geographical diversification strategy, carbon leakage, relocation, and halo effects should be investigated in the context of sustainability transitions in China.

Third is to explore how to connect Chinese outward FDI with local as well as global value chain. Chinese outward development finance and FDI are often criticized for allocating infrastructure projects that would bring political gain and satisfy leaders' selfish interests rather than local benefits (Dreher et al., 2014), and creating an unfavorable degree of dependency on China in terms of value chain as well as finance (Collier, 2018). They are also criticized for demanding fair treatment to host countries despite unfair treatment to foreign companies in the domestic market including forced joint companies with Chinese counterparts; insufficient protection of intellectual property rights; preferential treatment of state enterprises; and subsides from central and local governments (Chapter 8). These criticisms suggest China's outward FDI and exports narrow spaces for industries and business in host countries to gain economic benefits in the transitions to RES-E-based system.

Even if domestic manufacturers can hardly compete with Chinese ones and have to reply on Chinese solar PV cells and modules, distributed renewable energy access systems-stand-alone, off-grid renewable-based systems that can generate and distribute energy independently of a centralized electricity grid - still have a potential for job creation in many countries (REN21, 2020). Local community power enterprises may support the local economy by involving local companies in installation, racking and mounting, cabling, and wiring. However, it has to be balanced with LCOE (IRENA, 2020).

Given that a large-scale integration of RES-E into the grid requires the transformation to a capital-intensive, distributed, and smart grid-based electricity system, grid companies with smart grid will be platformers in the electricity system and generate the highest value added in the whole value chain. In reference to ongoing platform business, grid governance will be a decisive role in just transitions to the RES-E-based system, and RES-E technologies will fall into a low value-added segment. In fact, Chinese state grid companies acquire grid companies in the Philippines (Lema, 2007), Brazil (China Daily, 2017), Portugal, Italy, Greece (Xinhua, 2017), and Laos (RFA's Lao Service, 2021). It is a promising but challenging research agenda to be tackled in the future.

\section{References}

Braun, S. 2021. Is China's five year plan a decarbonization blueprint? $D W$ (5 March 2021), https://p.dw.com/p/3pfo9/, [accessed 21 March 2021]. 
China Daily, 2017. State Grid to buy remaining stake in Brazil's CPFL, (1 September 2017), https://www.chinadaily.com.cn/business/2017-09/01/content_31409824. htm/, [accessed 2 August 2020].

Collier, A. 2018. China Buys the World: Analyzing China's Overseas Investments, Palgrave MacMillan: Singapore.

Dreher, A., A. Fuchs, R. Hodler, B. Parks, P.A., Raschky, M.J. Tierney, 2014. Aid on demand: African leaders and the geography of China's foreign assistance. AidData Working Paper No. 3, AidData, https://ncgg.princeton.edu/new_ipes/2014/ papers/F915_rm1.pdf/, [accessed on 18 October 2019].

Hartmann, J., A.C. Inkpen, K. Ramaswamy, 2020. Different shades of green: Global oil and gas companies and renewable energy, J Int. Bus. Stud., https://doi. org/10.1057/s41267-020-00326-w.

Haskel, J., S. Westlake, 2018. Capitalism without Capital: The Rise of the Intangible Economy, Princeton University Press, Princeton.

IRENA, 2020. Renewable Power Generation Costs in 2019, International Renewable Energy Agency, Abu Dhabi, https://www.irena.org/-/media/Files/IRENA/ Agency/Publication/2020/Jun/IRENA_Power_Generation_Costs_2019.pdf/, [accessed 14 January 2021].

Khosla, R., A.S. Kamat, V. Narayanamurti, 2020. Successful transitions clean energy technology in emerging economies: Learning from India, China, and Brazil, Progress in Energy 2, 043002, https://doi.org/10.1088/2516-1083/abb52b.

Lema, K., 2007. China State Grid group wins Philippine power auction, Reuters (12 December 2007), https://uk.reuters.com/article/philippines-privatisation/ update-4-china-state-grid-group-wins-philippine-power-auction-idUKMAN2254 7220071212/, [accessed 2 August 2020].

Mori, A., 2019. Temporal dynamics of infrasystem transition: The case of electricity system transition in Japan, Technol. Forecast. Soc. Change 145, 186-194, https:// doi.org/10.1016/j.techfore.2017.05.00.

Mori, A., 2020. Foreign actors, faster transitions? Co-evolution of complementarities, perspectives and sociotechnical systems in the case of Indonesia's electricity supply system, Energy Res. Soc. Sci. 69, 101594, https://doi.org/10.1016/j. erss.2020.101594.

Mori, A., 2021. How do incumbent companies' heterogeneous responses affect sustainability transitions? Insights from China's major incumbent power generators, Environ. Innov. Soc. Tr. 39, 55-72, https://doi.org/10.1016/j.eist.2021.02.003.

REN21, 2020. Renewables 2020: Global Status Report, https://www.ren21.net/ wp-content/uploads/2019/05/gsr_2020_full_report_en.pdf/ [accessed 24 March 2021].

RFA's Lao Service, 2021. Laos Grants 25-Year Concession to Chinese Company to Manage Power Grid: Critics worry about increasing Chinese control over Laos' infrastructure, (16 March 2021), https://www.rfa.org/english/news/laos/grid03162021152622.html/, [accessed 19 March 2021].

Rifkin, J. 2019. The Green New Deal: Why the Fossil Fuel Civilization Will Collapse by 2028, and the Bold Economic Plan to Save Life on Earth, St. Martins Press, London.

Sachs, J.D., W.T. Woo, N. Yoshino, F. Taghizadeh-Hesary, 2019. Importance of green finance for achieving sustainable development goals and energy security, In: Sachs, J.D. et al. (eds.), Handbook of Green Finance: Energy Security and Sustainable Development, Springer Reference, 3-12, https://doi.org/10.1007/ 978-981-13-0227-5_13. 


\section{Akihisa Mori}

Teece, D, G. Pisano, A. Shuen, 1997. Dynamic capabilities and strategic management, Strateg. Manag. J. 18, 509-533, https://www.jstor.org/stable/3088148.

Xinhua, 2017. China's State Grid completes purchase of Greek power grid operator stake, China Daily (21 June 2017), https://www.chinadaily.com.cn/business/2017-06/21/content_29833439.htm/, [accessed 2 August 2020]. 